\title{
ANOTASI BIBLIOGRAFI \\ PENERAPAN MEDIA DAN MODEL PEMBELAJARAN UNTUK MENINGKATKAN MINAT TERHADAP PEMBELAJARAN SEJARAH
}

Oleh:

\section{Pipit Pitriani}

Email: pitrianipipit468@gmail.com

Program Studi Pendidikan Sejarah Fakultas Keguruan Dan Ilmu Pendidikan

Universitas Lambung Mangkurat

Banjarmasin

Susanto, H., \& Akmal, H. (2019). Media Pembelajaran Sejarah Era Teknologi Informasi (Konsep Dasar, Prinsi Aplikatif, dan Perancangannya). FKIP Universitas Lambung Mangkurat.

Buku ini berisi tentang pembahasan mengenai media pembelajaran sejarah pada era digital seperti sekarang ini. Pembahasan awal pada buku ini menjelaskan tentang konsep dasar mengenai media pembelajaran. Kemudian pembahasan nya berkembang menjadi tahapan-tahapan dalam menganalisis aplikatif pembuatan media pembelajaran sejarah. Pembahasan selanjutnya mengenai perancangan dan cara penggunaan media pembelajaran sejarah baik media berbasis online maupun Mobile Smartphone.

Susanto, H., \& Akmal, H. (2018). Efektivitas Penggunaan Aplikasi Pembelajaran Berbasis Mobile Smartphone Sebagai Media Pengenalan Sejarah Lokal Masa Revolusi Fisik Di Kalimantan Selatan Pada Siswa Sekolah Menengah Atas. HISTORIA: Jurnal Program Studi Pendidikan Sejarah, 6(2), 197-206.

Artikel ini berisi tentang penggunaan aplikasi pembelajaran sejarah berbasis Mobile Smartphone dalam mengenalkan sejarah lokal pada masa 
revolusi fisik di Kalimantan Selatan. Aplikasi pembelajaran berbasis Mobile smartphone ini menjadikan media pembelajaran sejarah mudah untuk dipahami oleh peserta. Dari artikel ini dapat kita ketahui bahwa penggunaan aplikasi Mobile Smartphone memberikan dampak yang baik. Dimana setelah menggunakan aplikasi Mobile Smartphonen nilai rata-rata peserta didik kelas XI IPS SMA Negeri 7 Banjarmasin mengalami peningkatan sekitar $41,72 \%$..

Mutiani, M., WARMANSYAH ABBAS, E. R. S. I. S., Syaharuddin, S., \& Susanto, H. (2019). Penerapan Transcript Based Lesson Analyses (TBLA) Sebagai Upaya Peningkatan Pembelajaran Sejarah Di Sma Negeri 7 Banjarmasin.

Laporan penelitian ini berisi tentang implementasi Model Transcript Based Lesson Analyses (TBLA) pada pembelajaran sejarah di SMA Negeri 7 Banjarmasin. Pelaksanaan Transcript Based Lesson Analyses (TBLA) pada mata pelajaran sejarah di SMA Negeri 7 Banjarmasin ini dirancang memiliki dua siklus. Setelah diterapkannya Transcript Based Lesson Analyses (TBLA) terjadi peningkatan dalam menyimpulkan materi secara konstektual dan kronologis pada peserta didik. Ada beberapa kendala dalam menerapkan (TBLA) di SMA Negeri 7 Banjarmasi seperti butuh pengaturan waktu yang lama, membutuhkan setting kelas, alat penunjang yang mumpuni, dan lain-lain.

\section{Simpulan Konseptual Anotasi Bibliografi}

Media pembelajaran adalah perantara untuk menyampaikan materi pembelajaran kepada peserta didik. Media memiliki peran yang sangat penting dalam pembelajaran. Media pembelajaran memudahkan peserta didik dalam memahami pengetahuan. Media dapat dikatan sebagai tempat untuk memperoleh informasi ataupun pengetahuan. Selain media ada juga model pembelajaran. Model pembelajaran adalah pola/acuan agar telaksananya pembelajaran seperti yang diharapkan dan terencana. Dengan adanya penerapan media dan model 
pembelajaran sejarah ini akan meningkatkan minat peserta didik terhadap pembelajaran sejarah.

Penerapan media pembelajaran sejarah era teknologi dapat dilakukan berbasis online maupun Mobile Smartphone. Implementasi dari media aplikasi Mobile Smartphone yaitu dengan memanfatkan berbagai fitur pada internet. Melalui fasilitas internet inilah yang akan membantu peserta didik dan guru dalam mendapatkan informasi. Dalam proses pembelajaran sejarah aplikasi pada Smart Phone dapat digunakan sebagai media. Pada dasarnya aplikasi pembelajaran dapat mempermudah peserta didik dalam mendapatkan dan mempelajari materi.

Penerapan model pembelajaran untuk meningkatkan minat terhadap pembelajaran sejarah dapat dilakukan dengan menggunakan model Transcript Based Lesson Analyses (TBLA). Model (TBLA) dapat menganalisis pembelajaran sejarah melalui transkrip dialog antara guru dan peserta didik. Dengan menerapkan Transcript Based Lesson Analyses (TBLA) dapat meningkatkan minat terhadap sejarah. 